Global Nest: the Int. J. Vol 1, No 1, pp 23-32, 1999

Copyright@ 1998 GLOBAL NEST

Printed in Greece. All rights reserved

\section{SOIL ADSORPTION BEHAVIOUR AND PHOTOMINERALIZATION BY PHOTOCATALYTIC MEMBRANES IMMOBILIZING TITANIUM DIOXIDE OF ATRAZINE AND INTERMEDIATES}

\author{
B. M. GAWLIK ${ }^{1 *}$ \\ A. MORONI2 \\ I. R. BELLOBONO² \\ H. W. MUNTAU ${ }^{1}$
}

\author{
${ }^{1}$ Joint Research Centre \\ of the Commission of the European Union; \\ Environment Institute; I-21020 Ispra (VA) (Italy) \\ ${ }^{2}$ Department of Physical Chemistry and Electrochemistry; \\ University of Milan; \\ Via C. Golgi, 19; I-20133 Milan (Italy)
}

*to whom all correspondence should be addressed

\title{
ABSTRACT
}

The soil adsorption behaviour of atrazine and its photodegradation intermediate 4,6-diamino-2-chloro-1,3,5$s$-triazine (I), was evaluated by measuring partition coefficients on five representative European topsoils using classical batch experiments. From this study, (I) appears to be less immobilised than atrazine itself, especially for typical agricultural soils. Consequently, (I) has a higher tendency to reach the saturated zones, and hence, the groundwater. In order to remove atrazine and its degradation products from groundwater prior to making it drinkable, photocatalytic degradation onto membranes immobilizing $30 \pm 3 \mathrm{wt}$. $\% \mathrm{TiO}_{2}$ has been investigated as a possible technology to mineralize these waters satisfactorily. For this purpose, experiments have been carried out using a pilot-plant facility, with $0.02-0.10 \mathrm{mmol} \mathrm{L}^{-1}$ solutions of atrazine, as well as of compound (I) and of 2,4,6-trihydroxy-1,3,5-s-triazine (II). When employing an excess of hydrogen peroxide as the oxidizing agent, the monitoring of chemical oxygen demand (COD), as well as control by HPLC, showed that (II) was a photostable degradation product, owing to its resistance to attack by hydroxyl radicals. On the other hand, when kinetic runs were carried out onto membranes in the presence of dissolved oxygen only or of sub-stoichiometric quantities of $\mathrm{H}_{2} \mathrm{O}_{2}$, (II) could be quantitatively mineralized. A mechanism has been proposed, based on the possible direct involvement of holes in the irradiated semiconductor surface, together with superoxide anions, these latter being produced by the reaction of conduction band electrons with dissolved oxygen. This mechanism, which is inhibited by an excess of hydrogen peroxide, owing to its reaction yielding hydroxyl radicals by any route, is also substantiated by previous experiments, carried out in the presence of ozone, with and without photocatalytic promoters.

KEY WORDS: Atrazine, soil adsorption, photodegradation, wastewater treatment.

\section{INTRODUCTION}

The European Chemicals Act (European Commission, 1979) foresees extensive and thorough testing of chemicals produced industrially and dispersed into the environment during use and consumption with regard to their toxicity, mutagenicity, terratogenicity and soil behaviour. The full dimen- 
sion of the problem derived from this directive becomes obvious when one considers that the European Commission's EINECS - European Inventory of existing commercial substances in the European Union - counts more than 95000 compounds (European Commission, 1987), most of which produce numerous degradation products in the environment. Most chemical products and their degradation products reach the soil compartment mainly along atmospheric deposition paths and finally enter the agricultural food chain; others are deliberately distributed onto agricultural land. To assess the risks of top soil or groundwater contamination according to specific soil properties, the European Commission adopted and modified OECD test guideline 106 (OECD, 1981) for the testing of adsorption/desorption behavior of chemicals in soil (European Commission, 1984; 1988).

An international laboratory comparison exercise was organized in the context of guideline modification and testing, and the chemicals selected for this exercise included atrazine (Herrmann, 1994). Before it was banned or restricted in use, this pesticide, during years of unlimited use in agricultural pest control, accumulated in topsoils throughout the European Union (Wauchope, 1978; Binstein \& Devillers, 1996). In recent times, there has been a growing concern about the threat to ground and surface waters as well as to drinking water quality caused by these accumulated atrazine residues (Ritter et al., 1994; Solomon et al., 1996; Dörfler et al., 1997; Mirgain et al., 1993). Large scale control and cleaning of agricultural run-off, rinsates and vertically percolating water for atrazine and other outdated chemicals is therefore mandatory. Biocide treatment methods include adsorption onto granular activated carbon and microbial degradation. Generally, however, these technologies do not bring a radical final solution to the problem, because they introduce residual hazards by simply transferring pollution from one phase to another, or do not achieve complete degradation, or they require further disposal.

Great attention has been paid in recent years to the photocatalytic degradation of pesticides and herbicides (Pelizzetti et al., 1990; Chester et al., 1993), particularly by employing titanium dioxide as a semiconductor, in suspension (Pelizzetti et al., 1990) or immobilized in thin films (Chester et al., 1993). Photocatalyzed degradation, however, has been reported to present no destruction of the heterocyclic ring of the $s$-triazine herbicides and the final, photochemically stable product observed under the experimental conditions of that work (Pelizzetti et al., 1990) was 2,4,6-trihydroxy-s-triazine (II). This is a strongly limiting factor, especially for groundwater to be used for human consumption.

Moreover, immobilization of a photocatalyst in a thin film does not allow the reaching of high yields, a value of $49 \mu \mathrm{mol} /$ Einstein having been observed for atrazine at $10 \mathrm{mg} / \mathrm{L}$ concentration (Chester et al., 1993). On the other hand, a 130 times higher yield was observed at the same concentration of atrazine, when photocatalytic, composite membranes immobilizing massive amounts (up to $30-40 \mathrm{wt} . \%$ ) of titanium dioxide and promoting photocatalysts were used with air saturated solutions, (Bellobono et al., 1995; Gianturco et al., 1997). Under these conditions complete mineralization up to $65 \%$ and higher occurred, as shown by total organic carbon (TOC) analysis. Furthermore, when employing trialkyl vanadates as photocatalytic semiconductor promoters (Gianturco et al., 1997) in membranes prepared by photografting (Bellobono \& Rhigetto, 1993; Bellobono \& Selli, 1995) with ozone as the oxygen supplier, much higher yields have been obtained with atrazine and other $s$-triazines as model molecules (1.3-1.9 mol/Einstein at "infinite" concentration). This value is about one order of magnitude higher than the maximum theoretical photochemical yield, even allowing for the photocatalytic action of vanadates to form $\bullet \mathrm{O}_{2} \mathrm{H}$ radicals from conduction band electrons, besides $\bullet \mathrm{OH}$ radicals produced from semiconductor holes. This has been explained (Gianturco et al., 1997) by a strong catalytic action of these vanadates, in the sense of dark catalysis, both on the starting substrates, and on their oxidation intermediates, but particularly on their photodegradation products. This new approach allowed transformation of the formerly laboratory-scaled photocatalytic process into a reliable technology able to exploit all known advantages of membrane technology besides that of immobilization of semiconductor and promoting photocatalysts.

The present paper describes a series of photomineralization studies on atrazine in aqueous solution as a possible technical solution to the treatment of atrazine-containing waters arising from former 
application on agricultural land. Possible soil sorption behaviour was deduced from the respective soil/ water partition coefficients measured on the five most frequent soil types of the European Union. It is generally accepted that the soil/water partition coefficient $\mathrm{K}_{\mathrm{d}}$ is closely related to the leaching behaviour of an environmental organic chemical and that, at least for non-ionic organics, the soil organic matter is of decisive importance for the sorption processes. Consequently, the most frequently used parameter to indicate the soil mobility of a given species is the soil organic carbon partition coefficient, $\mathbf{K}_{\mathbf{o c}}$. This coefficient is commonly used in models to assess the transformation and transport of environmental chemicals, and is of general use for the environmental risk assessment of organic chemicals (Lyman, 1982).

Hence, the above mentioned photomineralization studies were completed by studies on the soil adsorption behaviour of atrazine and 4,6-diamino-2-chloro1,3,5-s-triazine (I) on five topsoils which are representative for the region of the European Union. The utilization of the new version of the so-called EUROSOILS (Gawlik et al., 1996), in accordance with the OECD test guideline 106 (OECD, 1981), allowed an extrapolation to the assessment of the general European soil behaviour of atrazine (Gawlik et al., 1996).

\section{EXPERIMENTS}

Materials and Reagents. Atrazine was supplied by Promochem GmbH (Wesel, Germany), of $99.9 \%$ purity. The degradation products of atrazine - 2,4diamino-6-chloro-1,3,5-s-triazine (I) and 2,4,6trihydroxy-1,3,5-s-triazine (II) - were purchased from Aldrich (Italy), and they had purity of $95 \%$ and $98 \%$, respectively. $0.02-0.10 \mathrm{mmol} \mathrm{L}^{-1}$ solutions of atrazine and its photodegradation intermediates were prepared in ultra-pure water obtained by a Barnsted Easypure UV water treatment module. In some of the experiments hydrogen peroxide (34 wt.\%) from Carlo Erba Reagents was employed as the oxygen supplier. No buffer system was added, and $\mathrm{pH}$ varied from 5.4 to 4.6 during the irradiation runs. $\mathrm{CaCl}_{2} \cdot 2 \mathrm{H}_{2} \mathrm{O}$ for the soil sorption studies was purchased from Merck (Darmstadt, Germany). Centrifugation tubes $(25 \mathrm{~mL})$ equipped with a PTFE cap were supplied by Schott (Germany).

\section{Soil adsorption studies}

Soils: Five soils were used to measure the sorption isotherms. The soils prepared were the second edition of the so-called EUROSOILS, which are a set of recently introduced reference soils for sorption studies (Gawlik et al., 1996). The soils were selected in order to reflect the principal characteristics of the most typical soil types in the European Union, and are representative of $36.4 \%$ of the EU soils (Vetter \& Kuhnt, 1994). The sampling locations, physical properties and texture are listed in Table 1. Further information regarding pedological properties, major and minor constituents and organic pollutant content can be found elsewhere (Gawlik, 1998) .The soils were labelled ES-1n to ES-5n. Soil preparation was performed as recommended by OECD TG 106, i.e. the soils were air-dried, passed through a $2-\mathrm{mm}$ opening sieve and homogenized prior to bottling in brown borosilicate glass bottles. In order to prevent chemical degradation during the experiments owing to microbial activities, the soils were sterilized prior to use by g-irradiation.

Determination of Freundlich Isotherms: Freundlich isotherms were determined in a classical batch experiment based on the recommendations given in OECD TG 106. Only the adsorption of atrazine and its degradation product (I) were studied. A soil/solution ratio of 1:5 was chosen. Dried soil (4g) was weighed into $20 \mathrm{~mL}$ centrifugation tubes. $20 \mathrm{ml}$ of $0.01 \mathrm{M} \mathrm{CaCl}_{2}$ solution were added and the tubes were first covered by aluminum foil and then closed with a PTFE cap. The glass tubes were incubated for $12 \mathrm{~h}$, at $21 \pm 1^{\circ} \mathrm{C}$, in order to equilibrate the dry soil samples with the salt solution. After centrifugation at $2400 \mathrm{rpm}$ for $10 \mathrm{~min}$ and decantation, the soilcontaining tubes were re-weighed and $20 \mathrm{~mL}$ of the test solution were added. Atrazine and (I) were dissolved in a $0.01 \mathrm{M} \mathrm{CaCl}_{2}$ solution. A stock solution of $10 \mathrm{mg} \mathrm{L}^{-1}$ atrazine and $10 \mathrm{mg} \mathrm{L}^{-1}$ (I) was prepared. Further solutions of $0.2,1,2 \mathrm{mg} \mathrm{L}^{-1}$ were obtained by dilution with $\mathrm{CaCl}_{2}$ solution. The tubes were closed as described and incubated at the same temperature, for $24 \mathrm{~h}$, in order to guarantee equilibrium conditions. After centrifugation, aliquots of $2 \mathrm{~mL}$ were sampled, filtered with a $0.22 \mu \mathrm{m}$ filter, and analyzed as mentioned above. All tests were carried out in duplicate. The resulting equilibrium concentration was calculated on the difference of the initial concentration corrected by the dilution of the added 
$\mathrm{CaCl}_{2}$ solution for soil equilibration and the concentration at equilibrium. All batch experiments were run in triplicate for each initial concentration.

\section{Irradiation experiments}

Standard photocatalytic membranes (PHOTOPERM CPP/313), without any promoter of the semiconductor efficiency, were supplied by Chimia Prodotti e Processi (Cinisello Balsamo, Milan, Italy): they immobilized $30 \pm 3 \mathrm{wt} . \%$ of $\mathrm{TiO}_{2}$ and were prepared industrially at a pilot-plant, as described (Bellobono et al., 1995).

Irradiation experiments were performed by a PHOTOPERM WP module, illustrated in previous papers (Barni et al., 1995a, 1995b), purchased from Chimia Prodotti e Processi (Italy). The volume of solutions being treated was kept constant (20 L). Due to the use of low pressure mercury arc lamps, radiation was monochromatic $(254 \mathrm{~nm})$ in the semiconductor absorption range, and corresponded to $16 \pm 1 \mathrm{~W}$ of absorbed power. All the experimental work, analytical supervision of the irradiation experiments included, was carried out at the Environment Institute, Ispra.

\section{Analytical Determinations}

Adsorbed Organic Halogens (AOX): This technique was used to monitor the elimination of organically bound chlorine during the photocatalytic degradation of atrazine and (I). The analyses were performed using a DANI AOX-Analyzer 70.10 and software purchased from IDC Geräteentwicklungsgesellschaft mbH (Germany). Calibration curves were obtained using a $0.01 \mathrm{M} \mathrm{HCl}$ solution. The sample containing the unknown concentration of the substrate molecule was diluted 100 times prior to the analysis.

Chemical oxygen demand (COD): Chemical oxygen demand (COD) was used to quantify the concentration of carbon susceptible to oxidation in the test solutions. COD was measured based on the photometric determination of the decrease of chromate concentration after oxidation for $2 \mathrm{~h}$, at $148^{\circ} \mathrm{C}$, with potassium dichromate - sulphuric acid - silver sulphate. A COD kit (Cat. No. 91826) from Macherey-Nagel (Düren, Germany) together with a Model 45600 COD reactor from Hach Company (Loveland, USA) and a Model 100D photometer from Nanocolor (Velp Scientifica, Italy) were used for all the COD measurements.

Kjeldahl nitrogen determination: The nitrogen determinations by the Kjeldahl method were according to IRSA standard operation procedures (Blundo et al., 1994).

HPLC determinations: A Hewlett Packard HP 1050 quaternary pump equipped with an HP 1050 diode array detector, column oven, and autosampler was used for all chromatographic determinations. Acquisition and data-analysis were performed using the HP HPLC CHEMSTATION program. A Spherisorb ODS 2 column $(5 \mu \mathrm{m}, 250 \times 4 \mathrm{~mm})$, purchased from Hewlett-Packard, together with the respective pre-column of the same material were used as the stationary phase. A mixture $(30 / 70 \mathrm{v} / \mathrm{v})$ of acetonitrile (gradient grade, purchased from ABI, Italy) and $0.1 \mathrm{M}$ ammonium acetate under isocratic conditions was used for the determination of atrazine and (I) at $40^{\circ} \mathrm{C}$. For the quantification of $2,4,6-$ trihydroxy-1,3,5-s-triazine (II), the buffer solution was replaced by $0.05 \mathrm{M} \mathrm{H}_{3} \mathrm{PO}_{4}$.

\section{RESULTS AND DISCUSSION}

Soil Adsorption Behaviour. As can be seen from Table 1, atrazine will be more adsorbed than (I) in all five soils. The results obtained by the adsorption experiments confirm the important role of organic matter content for the adsorption of compounds of interest (ES 5n). However, the influence of the clay concentration is also of considerable importance (ES 1n). The results indicated a higher soil mobility for atrazine and (I) in soils like the French orthic luvisol or the dystric cambisol from Greece, both being typical European agricultural soils. Indeed, the problem of atrazine in some zones in France has been recently reported (Binstein \& Devillers, 1996; Mirgain et al., 1993) and confirms the hypothesis.

The obtained soil adsorption coefficients imply a possible transfer to lower soil regions in the case of soils similar to ES 2n, ES 3n and ES 4n, whereas atrazine will tend to be immobilized and hence can be mineralized in-situ by naturally occurring processes if soil properties are close to ES 1n or ES 5n. One may therefore expect, that, in areas which have similar soil properties to those of ES 2n, ES 3n and ES 4n, atrazine residues may threaten the quality of groundwater and other water bodies. In those cases, 
the application of photocatalytic degradation processes can be an interesting alternative for water treatment.

Photomineralization Experiments. In the experimental conditions of the present work, pseudofirst-order degradation kinetics were observed for both, atrazine and its degradation intermediate (I), owing to the low range of concentrations employed. This is perfectly consistent with results of previous work (Bellobono et al., 1995; Gianturco et al., 1997). When operating in the presence of hydrogen peroxide, an example of a typical kinetic curve is that shown in Figure 2, relative to a stoichiometric concentration of $\mathrm{H}_{2} \mathrm{O}_{2}$. From Figure 2, one can see that two degradation reactions of atrazine are in competition, i.e the substitution of the chlorine atom and the oxidation of the alkylic side chains .These studies prove that pathway $\mathbf{A}$ (Fig. 1) represents approximately $70 \%$ of the total degradation velocity whereas the remaining $30 \%$ may be attributed to pathway B (Fig. 1).

The presence of compound (I) as intermediate during photodegradation has been discussed else where (Pelizzetti et al., 1990). This justifies the presence of organic chlorine at the end of atrazine degradation kinetics, following the generally accredited scheme of photocatalytic degradation (Pelizzetti et al., 1990). Furthermore, when organically bound chlorine mineralization was practically complete, the percentage of oxidizable organic carbon (COD-data) remaining in stationary conditions corresponded to the stoichiometric formation of (II). Detection of (II) in the final solution by means of HPLC analysis pointed to the same conclusion.

The following mechanism of photodegradation is proposed (Fig. 1). Based on the analytical data (Number of peaks in the HPLC chromatograms and their development, HPIC-data, AOX and COD) the formation of the intermediates I4, I5, (I) (=I6) and (II) (=I9) was suspected. The disappearence of (I) for instance went along with a contemporary increase in the chlorine concentration (Fig. 3.) whereas the concentration of nitrogen species remained almost constant under these conditions, e.g. an initial organic nitrogen concentration of $4.1 \mathrm{mg} \mathrm{L}^{-1}$ in an experiment decreased only down to $3.6 \mathrm{mg} \mathrm{L}^{-1}$ after 400 min of irradiation and then remained unchanged.

This behaviour is the same as that observed in literature (Pelizzetti et al., 1990) when suspended semiconductors are used, and confirms that in the presence of hydrogen peroxide, even when operating with photocatalytic membranes, complete mineralization cannot be achieved (Gianturco et al., 1997).

Table 1. Soil adsorption behavior of atrazine and (I)

\begin{tabular}{|c|c|c|c|c|c|c|c|}
\hline Soil & Origin & FAO soil unit & Vegetation/Land Use & $\begin{array}{l}\text { Clay } \\
{[\%]}\end{array}$ & $\begin{array}{l}C_{\text {org }} \\
{[\%]}\end{array}$ & $\begin{array}{c}K_{o c} \\
\text { (atrazine) }\end{array}$ & $\begin{array}{r}K_{o c} \\
(I)\end{array}$ \\
\hline ES 1n & $\begin{array}{l}\text { Sicily } \\
\text { (Italy) }\end{array}$ & Vertic Cambisol & Meadow/Grassland & 69.15 & 3.29 & 142.5 & 48.8 \\
\hline ES 2n & $\begin{array}{c}\text { Peloponnesos } \\
\text { (Greece) }\end{array}$ & Rendzina & Broad-leaved trees & 21.4 & 2.39 & 92.8 & 31.1 \\
\hline ES 3n & $\begin{array}{l}\text { Wales } \\
\text { (U. K.) }\end{array}$ & Dystric Cambisol & Pasture/Grassland & 16.85 & 3.32 & 58.7 & 20.2 \\
\hline ES 4n & $\begin{array}{l}\text { Normandy } \\
\text { (Germany) }\end{array}$ & Orthic Luvizol & Wheat/Arable Land & 18.4 & 1.36 & 40.7 & 16.7 \\
\hline ES 5n & $\begin{array}{c}\text { Schl.-Holstein } \\
\text { (Germany) }\end{array}$ & Orthic Podzol & Conferous Forest & 3.95 & 4.43 & 306.3 & 104.2 \\
\hline
\end{tabular}




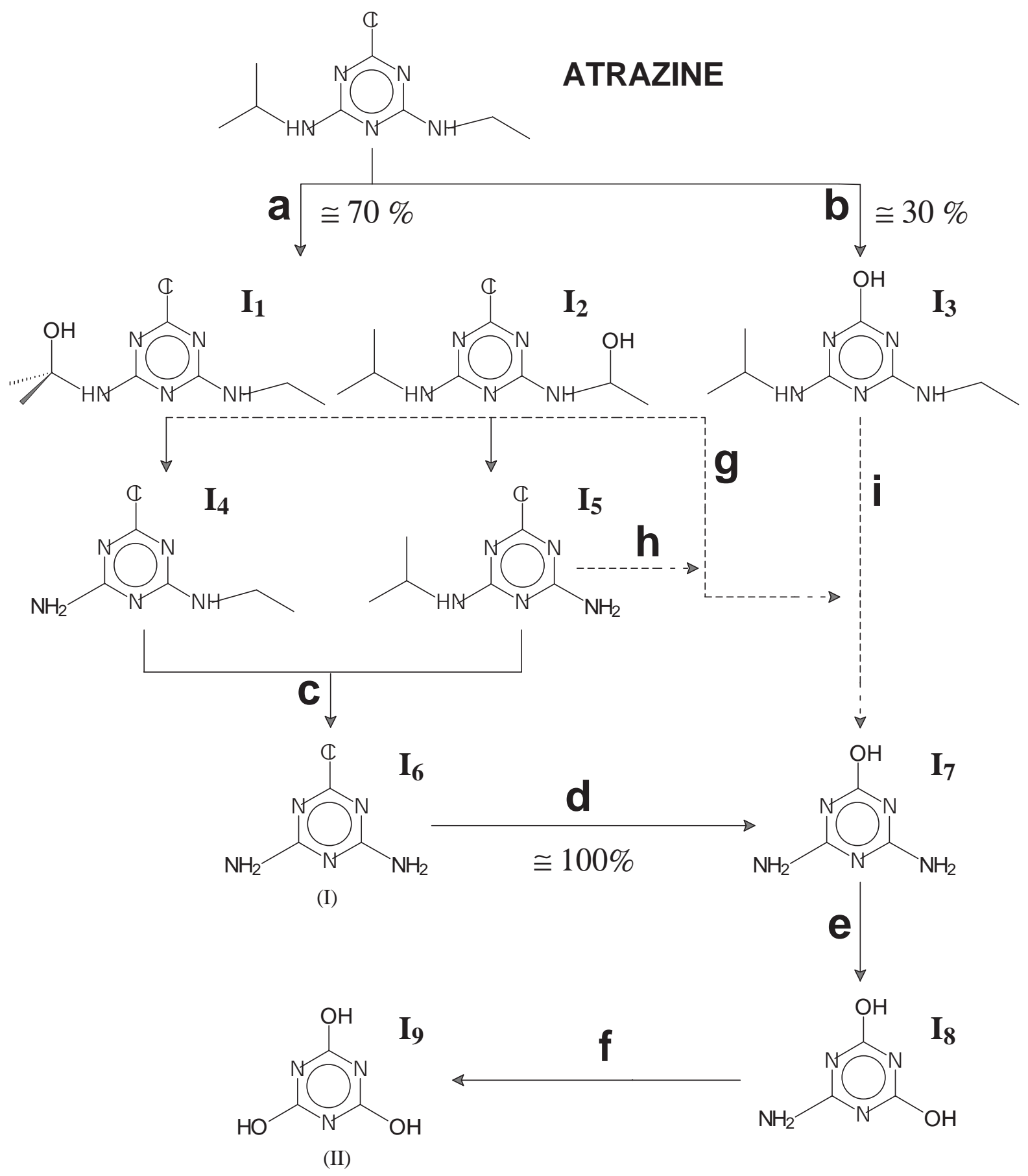

Figure 1. Reaction scheme for the photodegradation of atrazine 


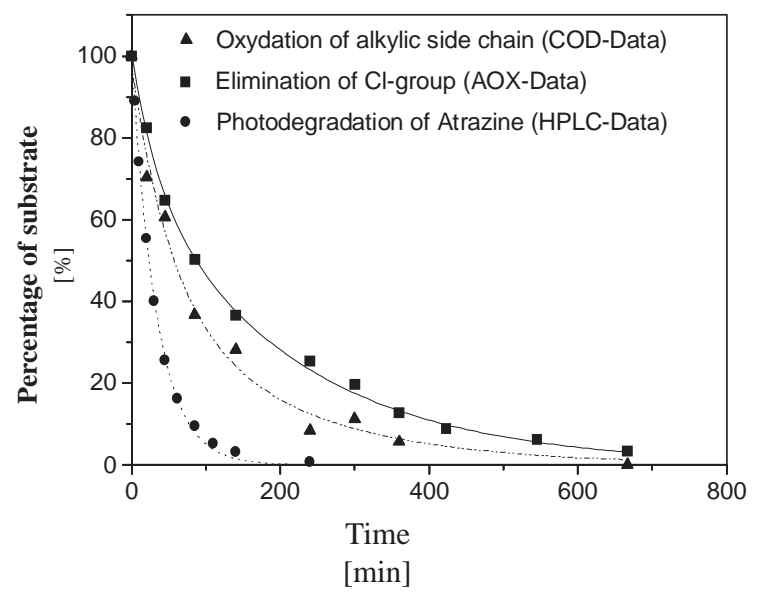

Figure 2. Comparison of the observed kinetics obtained organic bound chlorine, alkylic side chain and total substrate concentration by AOX, COD and HPLC-analysis. The initial concentration of atrazine in this run was $0.11 \mathrm{mmol} \mathrm{L}^{-1}$.

In order to check if this could be due to the influence of the $\bullet \mathrm{OH}$-driven radical mechanism, kinetic runs were carried out in the presence of an excess $\mathrm{H}_{2} \mathrm{O}_{2}$ or with a sub-stoichiometric amount, by employing compound (II) as reacting substrate.

Hydroxyl radicals may be formed from holes of the irradiated semiconductor surface, or from direct photolysis of $\mathrm{H}_{2} \mathrm{O}_{2}$ especially when using high-energy radiation as in the present work. However, it is also well known (Ollis and Al-Ekabi, 1993), that hydroxyl radicals may be formed by reaction of $\mathrm{H}_{2} \mathrm{O}_{2}$ with superoxide radicals or with conduction band electrons. One can assume that the photodegradation of (II) is based on the reaction of (II) with both the hole $\mathrm{h}^{+}$and the peroxide radical anion $\bullet^{\mathrm{O}_{2}}{ }^{-}$as proposed by the cited works. This hypothesis is confirmed by the data displayed in Fig. 3, where an increase of $\mathrm{H}_{2} \mathrm{O}_{2}$ concentration favours the following reactions:

$$
\begin{gathered}
\mathrm{O}_{2}^{-}+\mathrm{H}_{2} \mathrm{O}_{2} \rightarrow \mathrm{OH}^{-}+\mathrm{OH} \cdot+\mathrm{O}_{2} \\
\text { and } \\
2 \mathrm{~h}^{+}{ }_{\mathrm{VB}}+\mathrm{H}_{2} \mathrm{O}_{2} \rightarrow \mathrm{O}_{2}+2 \mathrm{H}^{+} .
\end{gathered}
$$

Both reactions compete with the mechanism proposed in Fig. 5.

As shown in Fig. 4, mineralization of (II) began to occur at acceptable rates, from the beginning, only when a stoichiometric or lower quantity of $\mathrm{H}_{2} \mathrm{O}_{2}$ was used. The same observation could be made when

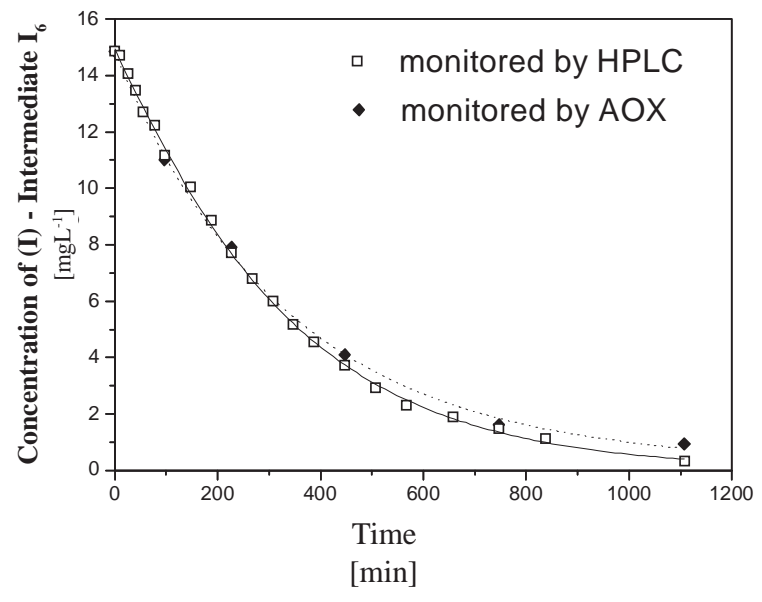

Figure 3. Comparison between the evolution of total concentration of (I) based on HPLC-data and the corresponding AOX-value

only dissolved oxygen was present in the treated solutions. Curves of Fig. 4, as a matter of fact, manifest that photodegradation of (II), in the presence of a reaction mechanism driven by $\bullet \mathrm{OH}$ radicals, is inhibited until these radicals are destroyed, or their concentration becomes sufficiently low, presumably by competitive reactions with peroxide radical anions leading to oxygen. From this time on, degradation of (II) may start at substantially the same rate as that observed in the absence of hydrogen peroxide.

As stated in a preceding work (Gianturco et al., 1997), direct oxidation by photogenerated holes onto

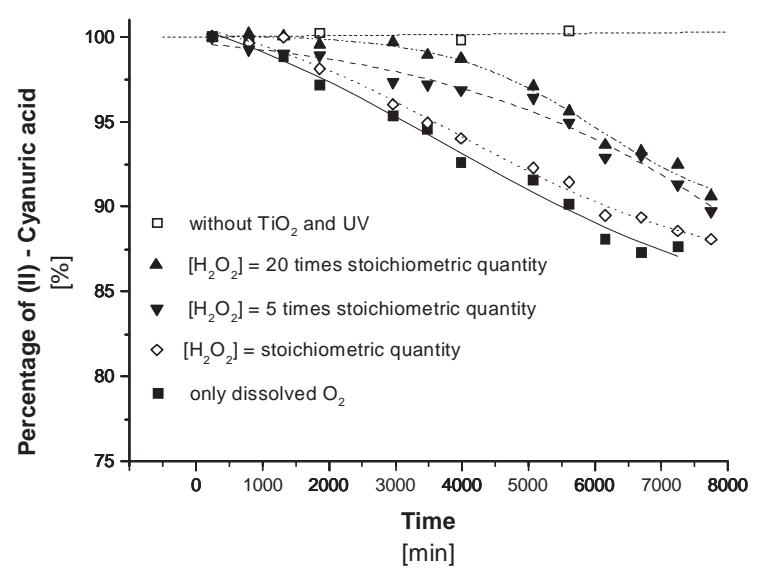

Figure 4. Observed kinetics of photodegradation of (II) - cyanuric acid - depending on $\mathrm{H}_{2} \mathrm{O}_{2}$ concentration. The initial concentration of (II) was $15.5 \mathrm{mg} \mathrm{L}^{-1}$. 
<smiles>Oc1nc(O)nc(O)n1</smiles>

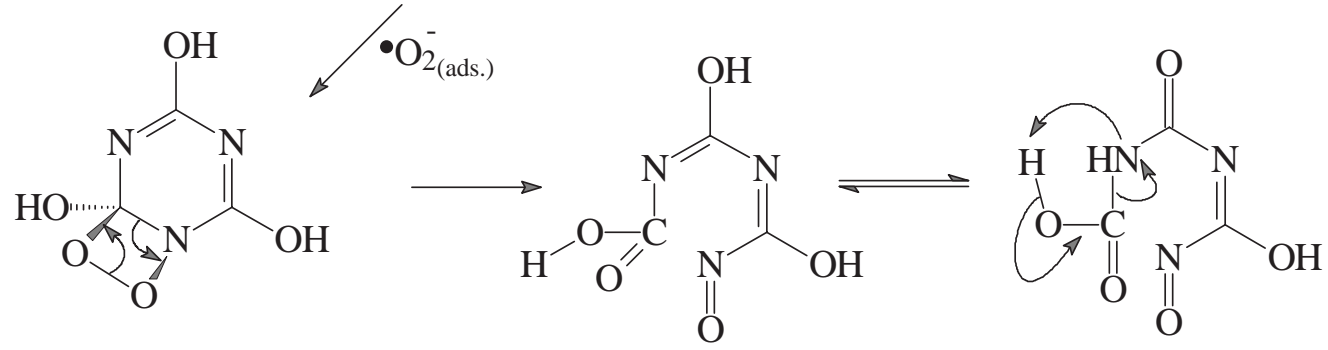

Competitive reaction: $\quad \bullet^{-} \mathrm{O}_{\text {(ads.) }}^{-}+\mathrm{H}_{2} \mathrm{O}_{2} \longrightarrow \bullet \mathrm{OH}+\mathrm{OH}^{-}+\mathrm{O}_{2}$

Figure 5. Reaction scheme for the photodegradation of (II) - cyanuric acid

the semiconductor surface, accompanied by reaction with the $\bullet \mathrm{O}_{2} \mathrm{H}$ and $\bullet \mathrm{O}_{2}{ }^{-}$acid/base couple, may be the reason for this behaviour (see Fig. 1). In this figure, only the attack by the superoxide radical anion is contemplated. The hydroxyl radical, as shown experimentally, and also on consideration of the molecular structure of (II), is unable to react with the substrate molecule, as no hydrogen abstraction is conceivable.

The time necessary to achieve photodegradation is long, because the adsorbed water on the surface on the semi-conductor occupies the holes on the same surface (Serpone et al., 1992) according to:

$$
\begin{aligned}
& \left\{\mathrm{Ti}^{4+}-\mathrm{O}^{2-}-\mathrm{Ti}^{4+}\right\}-\mathrm{OH}_{2}+\mathrm{h}^{+}{ }_{\mathrm{VB}} \rightarrow \\
& \left\{\mathrm{Ti}^{4+}-\mathrm{O}^{2-}-\mathrm{Ti}^{4+}\right\}-\mathrm{OH} \cdot+\mathrm{H}^{+}
\end{aligned}
$$

However, the measurement of the organic nitrogen confirms the photodegradation of the substrate molecule and the formation of a non-triazinic intermediate which degrades easily (Fig. 6). Therefore, one may conclude - as the catalytic photodegradation as discussed in this paper is driven basically by the - $\mathrm{OH}$ radicals $\left(\mathrm{H}_{2} \mathrm{O}_{2}\right.$ as source $)$ - that (II) is a stable product.

When $\mathrm{H}_{2} \mathrm{O}_{2}$ is absent and replaced simply by the oxygen present in the solution or suitable photocatalysators which are able to accelerate the scaven- ging effect of the oxygen with regard to the electrons of the conduction band, the role of $\mathrm{OH} \bullet$ is replaced by other oxidising agents such as $\bullet \mathrm{O}_{2} \mathrm{H}$ and $\bullet \mathrm{O}_{2}$. Thus, the oxidising effect of the generated hole on the surface can be used for the degradation of formerly stable compound (II).

\section{CONCLUSIONS AND PERSPECTIVES}

The widespread presence of atrazine deposits onto agricultural soil, due to its unlimited use in the past, has led to groundwater contamination by either atrazine or its metabolites in the case of poorly adsorptive soils (Wauchope, 1978; Dörfler et al., 1997; Binstein and Devillers, 1996; Ritter et al., 1994; Solomon et al., 1996; Mirgain et al., 1993). The testing experiments described here, on the basis of both OECD TG 106 and the EUROSOILS, which represent more than 36 per cent of the total soil-covered surface of the European Union, showed that the degradation products of atrazine tend to be less immobilized than the parent compound and that especially in areas covered by soil similar to ES 2, 3, and 4 atrazine or the less adsorptive metabolites may endanger the groundwater quality.

Soil surface run-off to connecting water bodies is likely to present a less significant transport route for the above mentioned metabolites because suspended 


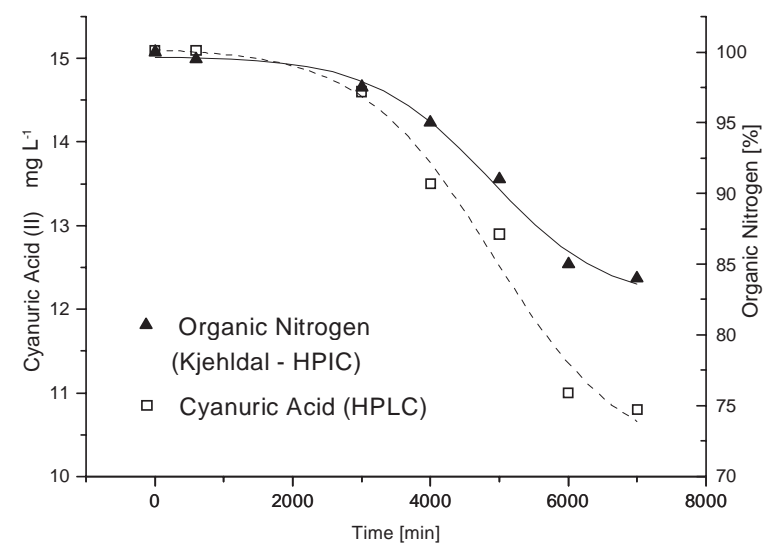

Figure 6. Comparison between decrease of concentrations of cyanuric acid (II) and organic nitrogen. The gap between both parameters indicates the formation of a non-triazinic intermediate.

soil particles are made up in particular of the highly adsorptive soil fractions, i.e. clay minerals and organic matter, and will therefore be deposited along with the adsorbed chemicals in sediment (Jones et al., 1982; Readman et al., 1993). Groundwater streams below poorly adsorptive soils which received atrazine treatment in the past need to be monitored for metabolite presence and the degradation products should be removed. In addition to traditional techniques such as adsorption on activated carbon or similar techniques, catalyzed photooxidation, as described here, seems to constitute a sound basis for further technological studies on a larger scale.

The Environment Institute in close cooperation with the regional government of Sardinia and a leading drinking water company (Ente Autonomo del Flumendosa, Cagliari) constructed a mobile laboratory on a van chassis, equipped with a combined ultrafiltration and catalyzed photooxidation test plant, and an analytical laboratory for chemical process control. The mobile laboratory will be employed in field studies dedicated to the purification of contaminated water of all kinds in order to re-use this resource for drinking water production in arid and semi-arid regions.

\section{REFERENCES}

Barni, B., Cavicchioli, A., Riva, E., Zanoni, L, Bignolli, F., Bellobono, I. R., Gianturco, F, De Giorgi, A., Muntau, H., Montanarella, L, Facchetti, S., Castellano, (1995a). Laboratory-scale photodegradation of phenol in aqueous solution by photocatalytic membranes immobilizing titanium dioxide, Chemosphere 30, 1847-1860.

Barni, B., Cavicchioli, A., Riva, E., Zanoni, L, Bignolli, F., Bellobono, I. R., Gianturco, F, De Giorgi, A., Muntau, H., Montanarella, L, Facchetti, S., Castellano (1995b). Pilot-plant-scale photodegradation of phenol in aqueous solution by photocatalytic membranes immobilising titanium dioxide, Chemosphere 30, 1861-1874.

Bellobono, I. R., Righetto, L. (1993). Photochemical production of composite membranes and reinforced plastics. In: New Aspects of Radiation Curing in Polymer Science and Technology, Fouassier, J. P., Rabek, J. J. (Eds.), Elsevier, London, UK, pp. 151-177.

Bellobono, I. R., Selli, E. (1995). Photochemical production of composite materials and membranes: Mechanistic aspects and applications. In: Current Trends in Polymer Photochemistry, Allen, N. S., Edge, M., Bellobono, I. R., Selli, E. (Eds.), Ellis Horwood, London, pp. 102-129.

Bellobono, I. R., Barni, B., Gianturco, F. (1995). Pre-industrial experience in advanced oxidation and intergral photodegradation of organics in potable waters and waste waters by PHOTOPERM membranes immobilizing titanium dioxide and promoting photocatalysts. J. Membrane Sci. 103, 139-147.

Binstein, S., Devillers, J. (1996). Evaluating the environmental fate of atrazine in France, Chemosphere 32, $2441-2456$.

Blundo, C. M., Campanella, L., Capri, S., La Noce, T., Liberatori, A., Pagnotta, R., Pettine, M. (1994). Metodi analitici per Acque, Quaderni 100 (2), 168-171.

Chester, G., Anderson, M., Read, H., Esplugas, S. (1993). A jacketed annular membrane photocatalytic reactor for wastewater treatment: degradation of formic acid and atrazine. J. Photochem. Photobiol. A: Chem. 71, 291299.

Dörfler, U., Feicht, E. A., Scheunert, I. (1997). s-Triazine residues in groundwater. Chemosphere 35, 99-106.

European Commission (1979). Directive 79/831/EEC. Sixth amendment to Directive 67/548/EEC on the classification, packaging and labelling of dangerous substances. Official Journal No. L 259 of 15.10.79, p. 10.

European Commission (1984). Annexe V. Official Journal No L 251 of 19.9.1984, p.1 
European Commission (1987). EINECS - European inventory of existing commercial substances, Advance edition, Office for official Publications of the European Communties, Luxembourg.

European Commission (1988). Annexe V. Official Journal No. L 133 of 30.5.1988, p. 1.

Jones, T. W., Kemp, W. M., Stevenson, J. C., Means, J. C. (1982). Degradation of atrazine in estuarine water/sediment system and soil. J. Environ. Qual. 11, 632-638.

Gawlik, B. (1998). Europäische Referenzböden für Sorptionsuntersuchungen (EUROSOILS) - Herstellung einer zweiten Version, Charakterisierung und Anwendung zur Bewertung von Alternativmethoden, European Commission Special Publication S.P.I. 98.135, 1998, p.148.

Gawlik, B., Sotiriou, N., Kuhnt, G., Karcher, W., Kettrup, A., Muntau, H. (1996). European reference soils as a common basis for the soil testing of environmental chemicals in the EU. Fresenius Environ. Bull. 5, 610-618.

Gianturco, F., Chiodaroli, C. M., Bellobono, I. R., Raimondi, M. L., Moroni, A., Gawlik, B. (1997). Pilot-plant photomineralization of atrazine in aqueous solution by photocatalytic membranes immobilising titanium dioxide and promoting photocatalysts. Fresenius Environ. Bull. 6, 461-468.

Herrmann, M. (1994). Evaluation of the EEC laboratory ringtest “Adsorption/Desorption of Chemicals in Soil”. In: EUROSOILS - Identification, collection, treatment, characterization, Kuhnt, G. and Muntau, H. (Eds.), European Commission, Special Publication No. 1.94.60. (1994), Ispra (Italy), pp. 81-147.

Lyman, W. J (1982). Adsorption coefficients for soils and sediments. In: Handbook of Chemical Property Estimation Methods, Lyman, W. J., Reehl, W. F., Rosenblatt, D. H., (Eds.), McGraw-Hill Book Company, New York (1982), Chapter 4.

Mirgain, I., Schenck, C., Monteil, H. (1993). Atrazine contamination of groundwaters in eastern France in relation to the hydrogeological properties of the agricultural land. Environ. Technol. 14, 741-750.

OECD (1981). Guidelines for Testing of Chemicals, Paris (1981).

Ollis, D., Al-Ekabi, H. (1993). Photocatalytic Purification and Treatment of Water and Air, 1993, Elsevier, Amsterdam.

Pelizzetti, E., Maurino, V., Minero, C., Carlin, V., Pramauro, E., Zerbinati, O, Tosato, M. L. (1990). Photocatalytic degradation of atrazine and other s-triazine herbicides. Enivron. Sci. Technol. 24, 1559-1565.

Readman, J. W., Albanis, T. A., Barcelo, D., Galassi, S., Tronczynski, J., Gabrielides, G. P. (1993). Herbicide contamination of Mediterranean estuarine waters: results from a MED POL pilot survey. Marine Pollution Bulletin 26, 613-619.

Ritter, W. F., Scarborough, R. W., Chirnside, A. E. M. (1994). Contamination of groundwaters by triazines, metolachlor, and alachlor. J. Contam. Hydrol. 15, 73-92.

Serpone, N., Lawless, D., Terzian, R., Meisel, D. (1992). Redox mechanisms in heterogeneous photocatalysis. The case of holes versus hydroxyl radical oxidation and free versus surface bound hydroxyl radical oxidation processes. In: Electrochem. Colloids Dispersions, R. A. Mackay and J. Texter (Eds.), VCH, New York, pp.399416.

Solomon, K. R., Baker, D. B., Richards, R. P., Dixon, K. R., Klaine, S. J., La Point, T. W., Kendall, R. J., Weisskopf, C. P., Giddings, J. M., Giesy, J. P., Hall Jr., L. W., Williams, W. M. (1996). Ecological risk assessment of atrazine in North American surface waters. Environ. Toxicol. Chem. 15, 31-76.

Vetter, L., Kuhnt, G. (1994). Methodological aspects of reference soil sampling. In: EUROSOILS - Identification, collection, treatment, characterization, Kuhnt, G. and Muntau, H. (Eds.), European Commission, Special Publication No. 1.94.60., Ispra (Italy), pp. 31-40.

Wauchope, R. D. (1978). The pesticide content of surface water draining from agricultural fields - a review. J. Environ. Qual. 7, 459-472. 